\title{
A Comparative Study on Power and Solidarity in an EFL Classroom Based on Turn-taking Theory
}

\author{
Cui Jie*, Wang Zhonghui \\ Mailbox 708, Faculty of Geomatics, Lanzhou Jiaotong University, Lanzhou, Gansu province 730070
}

Keywords: Turn-taking; Power; Solidarity; Teacher-student relationship

Abstract: Based on turn-taking theory, this paper makes a comparison between intensive reading class and oral class respectively in an EFL classroom from the perspective of teacher-students' power and solidarity relationship. Furthermore, some pedagogical implications to facilitate the teaching and learning performance are proposed from this perspective.

The terms and related concepts about POWER and SOLIDARITY were firstly introduced into sociolinguistics by the social psychologist Roger Brown (Brown \& Ford, 1961). Interpersonal relationships have been described as varying along both vertical and horizontal dimensions (Hall et al., 2005). The vertical dimension of relationships refers to the power or status differences between individuals (Hall et al., 2005). The horizontal dimension means the solidarity, which refers to the degree of interpersonal closeness between individuals and is a function of factors such as perceived similarity, liking, and time spent together. These two relationship dimensions are believed to impact a variety of interpersonal perceptions and behaviors.

It is well-known that in the classroom, teachers have strong power on students, especially in Chinese culture. The aims of this study is to find out the differences of the characteristics of the language between English majors and their teachers on two different types of class: intensive reading class and oral class based on the turning-taking theory and disclose the power and solidarity relationship between them; furthermore, to make pedagogical implications on these two types of classes.

\section{Turn-taking}

The turn is the basic unit of organization for conversation. The concept of turns was proposed by $\mathrm{H}$. Sacks, E.A. Schegloff \& G. Jefferson in 1974 firstly. According to Sacks et al. (1974), turn-taking mechanism can be described as two components: turn-constructional component and turn-allocation component, and a set of turn- constructional rules.

In two-party conversations, the different degree of controlling over the interactions is significant in term of turn-length and turn-initiating. Besides, compared with conversations in literary texts, the face-to-face conversations have more lapses, interruptions and pauses. Therefore, in this study, turn-length, turn-initiating, interruptions and overlaps are selected as turn-taking variables for quantitative and qualitative analyses. 


\section{Research Design}

This study will use the turn-taking produced by two teachers (the teacher of the intensive class is a Chinese while one of the oral class is an American) and 36 Chinese sophomores majored in English in Foreign Languages College, Lanzhou Jiaotong University. Three turn-taking variables - turn-length, turn-initiating, interruptions and overlaps will be processed for quantitative and qualitative analyses. The data are transcripts which are all recorded between teachers and students in the formal EFL classroom. The total time of each audio file is about 100 minutes.

\section{Results and Discussion}

\subsection{The Analyses of Turn-length}

\subsubsection{In Intensive Reading Class}

The concrete tables of the total and average turn-length of the teacher and the students in intensive reading class has been shown as follows:

Table 1 Analyses of turn-length in intensive reading class

\begin{tabular}{cccc}
\hline $\begin{array}{c}\text { Tutrkiength } \\
\text { Subjects }\end{array}$ & Numbers of turn & Time duration & Average time duration \\
\hline Teacher & & & \\
Students & 180 & 83 min48s & $27.9 \mathrm{~s}$ \\
Total & 166 & 13 min02s & $4.7 \mathrm{~s}$ \\
\hline
\end{tabular}

From the table 1, we can easily see that in intensive reading class, there is a big difference in the time duration of turns. The total and average time duration of the teacher's turns is $83 \mathrm{~min} 48 \mathrm{~s}$ and 27.9s compared with $13 \mathrm{~min} 02 \mathrm{~s}$ and $4.7 \mathrm{~s}$ produced by students. As mentioned by Herman (1995), hyper-dominant addresser might produce turn length disproportionately to show his power. Therefore, from the perspective of turn-length, the teacher holds the absolute power on the students in intensive reading class.

\subsubsection{In Oral Class}

Table 2 is shown concrete tables on the turn-length of the teacher and the students respectively in oral class.

Table 2 Analyses of turn-length in oral class

\begin{tabular}{cccc}
\hline $\begin{array}{c}\text { Turn-length } \\
\text { Subjects }\end{array}$ & Numbers of turn & Time duration & Average time duration \\
\hline Teacher & & & \\
Students & 193 & 38 min57s & $11.2 \mathrm{~s}$ \\
Total & 402 & 18 min $11 \mathrm{~s}$ & $5.7 \mathrm{~s}$ \\
\hline
\end{tabular}

There is also the difference in the time duration of the teacher's turns and that of the students' turns. Therefore there is still participatory disproportion between the teacher and the students, the teacher still holds the power on the students in oral class. However, it is obvious that the average of turn-length of the teacher in intensive reading class is much more than that in oral class. What is more, through the observation, in oral class, the students have much more chances to voice their own ideas 
and the restrictive feeling in oral class is weaker than that in intensive reading class. It proves that there is still intimacy and closeness between the teacher and students in oral class and their relationship does not only include the power but also the solidarity.

\subsection{The Analyses of Turn-initiating}

In two-party conversation, the speaker who always initiates a turn is the powerful party who maintains the dominant place, and the speaker who always produces the responsive turns is the powerless party who maintain the subordinate places.

\subsubsection{In Intensive Reading Class}

By analyzing the transcription of the tape-recording, it shows that the teacher is the one who initiates and terminates the turns from the beginning to the end both in intensive reading class and in oral class. Let's see examples in intensive reading class firstly:

Sample 1:

T: OK. So boys and girl, are you ready to star?

S: Yes.

T: OK. Let's start the class. Good morning, class

S: Good morning, Sir.

(At the beginning of the second section of the class after a break)

T: All right, we'll move on now. We'll get over the next page....

Sample 2:

(Because no students answer the question, so the teacher puts forward another one)

$\mathrm{T}$ : OK. Let me ask the next one. In your mind, is the religion the same as superstition?

S: No.

Sample 3

T: Five you don't need to finish. And also finish the Exercise 7, OK? So, so many for you exercise. Today we stop here and see you next time. Goodbye, students.

S: Goodbye, Sir.

Example 1 is excerpted from the very beginning of each sections of this intensive reading class. Example 2 takes place during the teaching process. Example 3 can be treated as turn-terminating. Obviously, it is the teacher who initiates the turns every time the students have no such right to terminate or dismiss the class. According to Linell (as cited in Jorgensen 1998), the initiatives as a tool used by the powerful speaker shows his dominance. The teacher in intensive reading class has the absolute power on the students. There is no solidarity found in the perspective of the turn-initiating.

\subsubsection{In Oral Class}

Now the example on turn-initiating in oral class will be presented in this part:

Sample 1:

T: Good morning, everyone.

S: Good morning, Sir.

(At the beginning of the second section of the class after a break)

T: Is everyone back? Yeah, let's begin.

Sample 2:

$\mathrm{T}$ : ...opposite side of the school, all right. Still some problems. OK, let's try another thing. We have then main gate, I want you to write the directions to get to your dormitory right now.

Sample 3:

T: OK, that's all for today. Wish you good luck in the final exam. Goodbye, students. 


\section{S: Goodbye, Sir.}

In Example 1, it is the teacher who initiates two turns. In Example 2, the teacher finishes one topic and starts another one. Example 3 is the terminating turns, which are also initiated by the teacher. In these examples, all the turns took by the students are the responsive turns and orders put forward by the teacher. The teacher holds the absolute power on the students. There is no solidarity between them.

\subsection{Interruptions and Overlaps}

It is ordinary that the powerful speaker always employs interruptions and overlaps as the strategies to control the conversation (Li \& Shen, 2003).

\subsubsection{In Intensive Reading Class}

Table 3 Analyses of interruptions and overlaps in intensive reading class

\begin{tabular}{ccc}
\hline Simes & $\begin{array}{c}\text { Teacher to } \\
\text { students }\end{array}$ & Students to teacher \\
\hline Interruptions & 3 & 0 \\
Overlaps & 8 & 1 \\
\hline
\end{tabular}

From the table 3, we can see that the times of the teacher's interrupts are 3 and overlaps are 8 . The students do only once overlaps to the teacher and do not interrupt the teacher during the whole class. So the teacher is the powerful one, the students are the powerless and maintain the passive and subordinate in the communication. There is no solidarity between them.

\subsubsection{In Oral Class}

The quantitative analyses of times of interruptions and overlaps used by the teacher and the students in oral class will be shown as follows:

Table 4Analyses of interruptions and overlaps in oral class

\begin{tabular}{ccc}
\hline Times & $\begin{array}{c}\text { Teacher to } \\
\text { students }\end{array}$ & Students to teacher \\
\hline Interruptions & 3 & 1 \\
Overlaps & 0 & 0 \\
\hline
\end{tabular}

From the table 4, we can see that in oral class, there is no overlap occurring and the interruptions appear 4 times, 3 of which are used by the teacher to the students. And one is used by the students to the teacher. Unlike what has been analyzed from the intensive reading class, we cannot find the significant difference from the above tables. Therefore from the perspective of interruptions and overlaps, the power and force of the teacher is not as strong as that in intensive reading class. The relationship between the teacher and students tends to less power and more solidarity.

\section{Summary and Implication}

Compared with the power-oriented relation between the teacher and students in intensive reading class, the power and force of the teacher is weaker in oral class, the relationship between the teacher and students is relatively solidarity-oriented.

Since the teachers are always in the dominant and controlling position in classrooms, they should 
pay attention to the proper degree when exerting the power. There are some implications for the teachers to construct the harmonious relationship between the teacher and students in the classroom: (1) Developing creative thinking of students. The teacher should take the student's curiosity, inquisitiveness and thirst for knowledge as the starting point to develop their awareness of the innovation. (2) Establishing equality in conversations. Both the teacher and students are ready to open their minds and accept the different voices from each other. (3) Constructing harmonious relationship in class. The teacher should use his power positively to establish the easy and relax atmosphere and promote the development of this harmonious relationship between the students and himself. As a result, the students can learn in a better way and the teacher can function perfectly in the classroom.

\section{Acknowledgements}

Youth Fund of Lanzhou Jiaotong University2015043

National Natural Science Foundation of China (41561090)

\section{References}

[1] Brown, R. \& Ford, M. Address in American English [J]. Journal of Abnormal and Social Psychology, 1961, 62(2): 378-385.

[2] Brown, R. \& Gilman, A. The Pronouns of Power and Solidarity [A]. In Sebeok, T. A. (ed.) Style in Language [C]. Cambridge: MIT press, 1960: 253-276. Also in Giglioli, 1972: 252-282.

[3] Hall, J., Coats, A., Erik, J., Le Beau. \& Smith, L. Nonverbal Behavior and the Vertical Dimension of Social Relations: A Meta-analysis [J]. Psychological Bulletin, 2005, 131(6): 898-924.

[4] Herman, V. Dramatic Discourse: Dialogue as Interaction in Plays [M]. London: Routledge, 1995.

[5] Sacks, H., Schegloff, A \& Jefferson, G. A Simplest Systematics for the Organization of Turn-taking for Conversation

[J]. Language, 1974, 50(4): 696-735

[6] Contemporary Linguistics, 2003, 5(1): 25-32.

Yi Xiuqing, Wang Xiaoliang. A Turn-taking Approach to the Dynamic Balance of Power Relations and Characterization of A Passage to India Journal of Southwest Jiaotong University, 2010, 11(4): 36-40. 